\title{
Horse and Herald: Posidippus' Equestrian Angelia
}

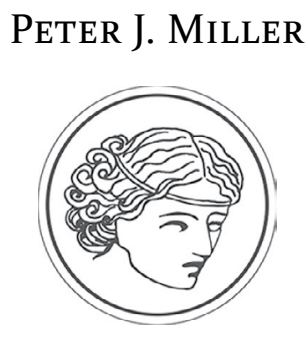

ABSTRACT / RÉSUMÉ

Posidippus' epigrams for equestrian victors (the Hippika, AB 71-88) build on epinician convention by maintaining the central role of the herald's proclamationthe angelia-in the representation of athletic achievement. In a few of these epigrams, however, Posidippus embeds the horse itself in postvictory rituals. For example, the horse brings the crown to the victor, replacing the figure of the herald who announced and crowned victors; or, in a narrative of the race's aftermath, the horse, incredibly, chooses the victor. Posidippus' horses, therefore, act as causal agents for the glory of their owners, and his detailed descriptions transform the horse from flesh-and-blood equine to everlasting (literary) monument.

Les épigrammes de Posidippe sur les victoires équestres (les Hippiques, 71-88 A.-B.) s'appuient sur une convention poétique propre aux épinicies qui maintient le rôle de la proclamation du héraut - l'angelia - dans la représentation de la réussite athlétique. Cependant, dans quelques-unes de ces épigrammes, Posidippe intègre le cheval lui-même au rituel marquant la victoire. Par exemple, le cheval apporte la couronne au vainqueur en remplacement de la figure du héraut qui annonce et couronne les vainqueurs ; ou encore, dans le récit de l'après-course, le cheval choisit, de façon surprenante, le vainqueur. Les chevaux de Posidippe interviennent donc en tant qu'agents causaux dans la gloire de leur propriétaire. Ses descriptions détaillées transforment ainsi l'être de chair et de sang qu'est le cheval en un monument (littéraire) éternel.

It is a privilege to be included in this collection in honour of Nigel Crowther, whose work, especially Athletika (2004), is ever-present on my desk. I thank Kevin Solez for inviting my contribution and the anonymous readers for the journal, whose comments improved my paper. The audience at CAMWS-SS (Atlanta, 2016) also offered valuable suggestions. Adriana Brook, Carla Manfredi, Brett Stine, and Carolyn Willekes generously read earlier drafts of this paper, and their comments and criticisms have greatly improved the final version. Any errors or omissions that remain are my own. 


\section{INTRODUCTION}

Posidippus' oeuvre ${ }^{1}$ was extended by the 2001 publication of the Milan Papyrus, a roll containing dozens of new poems. ${ }^{2}$ These short epigrams were divided, whether by the poet himself or a compiler in his lifetime, into categories with headings. ${ }^{3}$ Here, I look at the Hippika, a series of epigrams written for Panhellenic victors, and I contextualize them in the mode of athletic praise poetry: that is, I consider Posidippus as a poet whose poems evoke the herald's proclamation (or angelia) - the victor's name, father's name, event, and age group-but also modify the proclamation for rhetorical and ideological effect. ${ }^{4}$ Posidippus' epigrams therefore provide a compelling lens through which to analyze the representation of the glory of athletic victory in a genre on the border between literature and inscription. ${ }^{5}$

Posidippus' Hippika represent a reawakening of the literary memorialization of athletic achievement. ${ }^{6}$ Epinician vanished after the deaths of Pindar and Bacchylides (with the exception-seemingly only one-of Euripides' “epinician” for Alcibiades: PMG 755). Despite the 150- to 200-year gap between Classical epinician and Posidippus, and despite the change of form (inscriptional or pseudo-inscriptional; elegiac instead of lyric metre), Posidippus' Hippika continue to base their encomia on a modification and modulation of the angelia.

The herald's proclamation was at the core of Classical epinician song: the proclamation enunciated by the herald after victory, an ephemeral speech act that changed the status of one competitor to victor, is one of the central

' I cite Posidippus throughout from the Center for Hellenic Studies' online edition (Angiò, Cuypers, Acosta-Hughes, and Kosmetatou 2016). English translations are my own unless cited otherwise.

${ }^{2}$ For a papyrological description of the Milan Papyrus, see Bastianini and Gallazzi 2001; Krevans 2007. On the discovery of the papyrus and its initial reception, see Bing 2009: 177-193. The absence of author headings and the fact that two of the poems ( $\mathrm{AB} 15$ and 68) were previously known to be by Posidippus argue strongly for his authorship; see Krevans 2007: 142. Others (e.g., Lloyd-Jones 2003), however, think that Posidippus is not necessarily the sole author. The papyrus has been dated to the late third or early second century BC. Posidippus was active from the 280 os to the $240 \mathrm{~s}$ ВC, so he could have had a hand in its creation (Bing 2009: 178-179).

${ }^{3}$ On the arrangement of the poems of the Hippika, see Fantuzzi 2004.

4 The original proclamation of the herald can be reconstructed through literary and material evidence: see Wolicki 2002.

${ }^{5}$ In addition, his epigrams are primary sources for athletics in the Hellenistic period, an area of study that has flourished lately: see Mann, Remijsen, and Schaff 2016. On the importance of sports in Hellenistic Egypt specifically, see Fantuzzi 2005 and Remijsen 2010.

${ }^{6}$ Posidippus' epigrams engage with epigrammatic motifs from the corpus of agonistic epigrams, though that relation is beyond the bounds of this paper. I intend to pursue Posidippus' indebtedness to Archaic and Classical agonistic epigram in a subsequent article. 
generic elements in epinician song. ${ }^{7}$ The connection between the herald and the epinician singer does not exist solely in the modern critical imagination, since heralds and representations of heralds persist throughout the epinician chorus. At times the singer takes on the role of the herald (e.g., Pind. Ol. 7.20, 9.25-29; Pyth. 9.1-4; Nem. 4.73-75, 6.57-61; cf. fr. 7ob.23-25). The song itself may be an angelia (e.g., Pyth. 2.3-4; cf. Pyth. 2.67) or describes the initial proclamation or the reception of the angelia (e.g., Ol. 4.3-5, 13.100; Pyth. 1.30-33). Finally, the victor may also be the herald (Ol. 5.8; Isth. 3.11-13) ${ }^{8}$ Indeed, Plutarch even reports that Themistocles was once asked whether he wanted to be Homer or Achilles, to which he responded, "Would you rather be the herald or the victor at the Olympic Games?” (Mor. 185a). While Posidippus engages with this generic element in epinician song, both the changed form of epigram and the changed social and political context of the Ptolemaic court have contributed to alter the representation of the angelia in the Hippika. Posidippus' epigrams are therefore generic hybrids, at once epigrammatic and epinician. ${ }^{9}$

Posidippus' use of the epigram form, of course, suggests the possibility that his poems were originally inscribed on monuments and only later collected. Even before the discovery and publication of the Milan Papyrus, Posidippus was known as a poet of epigram; an inscription at Thermon from 263/262 вС identifies "Posidippus, the poet of epigram, from Pella."1o "Poet of

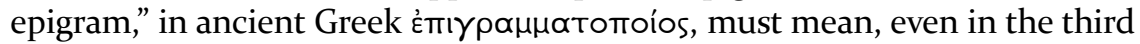
century ВС, a poet of inscriptions (as Bing remarks, it is "virtually a terminus technicus")." Therefore, we can speculate with a great degree of certainty that Posidippus composed epigrams for the traditional medium of stone and the new medium of papyrus. ${ }^{12}$ It may never be possible, barring archaeological discoveries, to ascertain whether Posidippus' epigrams were originally on monuments. ${ }^{13}$ Regardless, their early collection in an anthology suggests that

7 On the centrality of angelia to epinician and epigrammatic memorialization of athletic victory, see Day 1994: 63-65; 2010: 198-227. See also Nobili 2016: 159-171.

${ }^{8}$ On the motif of the angelia in epinician song more generally, see Nash 1990 and Nünlist 1998.

9 On Ergänzungspiel, Bing's term for Hellenistic "play" with the quasi-inscriptional aspect of epigrams, see Bing 2009: 85-105; for more on literary epigram's "play" with inscribed antecedents, see Bruss 2010: 119-123.

${ }^{10}$ Bing 2009: 180 .

${ }^{11}$ Bing 2009: 182; italics in original.

${ }^{12}$ For more on Posidippus' interest in inscriptions and scrolls, see Bing 2009: 177-193.

${ }^{13}$ Fantuzzi and Hunter 2004: 283-349. Bing observes that literary epigram continues to use the motifs of inscriptions, which makes distinguishing "genuine" and "literary" epigram difficult (Bing 2009: 204); see also Bettenworth 2007. I largely follow Bing's approach by assuming that Posidippus exploited the quasi-inscriptional status and engaged with his reader's expectations for epigrams and inscriptions in composing his poems (see Bing 2009: 214). 
the poems were initially conceived, or could be understood, without reference to a physical form. ${ }^{14}$

Even if the Hippika can be understood without physical dedications, they are nonetheless intricately engaged with monuments: they are full of appeals to autopsy, and the poems construct audiences at the Panhellenic Games sanctuaries, sites that were littered with extraordinary and expensive statues and monuments. Posidippus' poems describe the ostensible monument that bears them in such a way as to permit the imagination of the viewer to (re-)construct the statue or dedication. ${ }^{15}$ Some statues speak to us (e.g., $\mathrm{AB} 72,73,75,78$, etc.), while some narrate in the third person (e.g., $A B$ 74). Posidippus plays with the expected conventions and makes epigrams-whether inscribed or not - that are still grounded in actual epigrammatic practice. The epigrams are therefore sophisticated poetic constructs, as much in dialogue with art and memorialization as Pindar's and Bacchylides' earlier epinician. ${ }^{16}$

\section{THE HIPPIKA AND EPINICIAN}

The focus on evoking a visual context and on bringing into the "mind's eye" a vision of a monument has taken the form in the Hippika of describing horses. ${ }^{17}$ The Hippika are, unlike the corpus of Classical epinician song, only for equestrian victors in the variety of single-horse and chariot contests at the Panhellenic games (and, importantly, the Ptolemaia). While horses play a role in Pindar and Bacchylides, horses in the Hippika, as befits its name, are central. Posidippus' descriptions in these poems focus on the horse-in particular, its body and bodily characteristics - to the near exclusion of jockeys, charioteers, or even the patron who owned the horses and presumably commissioned the poem. The reader/viewer is invited to look at horses' indefatigable bodies ( $\mathrm{AB} 72.1-2)$, stretched out and drawing breath (AB 72.1-2), easily bearing burdens ( $A B$ 73.2), with undefiled chests ( $A B$ 74.7-8), running on the tips of their hooves (AB 76.1), washed in the Alpheus River (AB 84.1-2), and crowned again and again.

${ }^{14}$ On early epigrammatic collections and the limitations of the evidence, especially in the case of Simonides, see Sider 2007. Krevans detects an "ironic contrast between the fictional, inscriptional settings of these poems on tombstones and statues and their cramped new quarters in this book roll" (Krevans 2007: 143).

${ }^{15}$ On deictics in inscribed epigram in the Archaic and Classical periods, see Day 2010: 112-120. As Bing and Bruss observe, literary epigram borrows deixis, but "there is no 'there' there" (Bing and Bruss 2007: 8).

${ }^{16}$ On epinician song's interaction with statues and physical monuments (e.g., Pind. Ol. 6, Nem. 5), see Steiner 1998 and Thomas 2007.

${ }^{17}$ The play between the instant of victory and the memorialization of that instant is important throughout the Hippika. That is, Posidippus' epigrams are ecphrastic in the ancient sense (i.e., they have energeia: see Webb 2009: 87-106) and ecphrastic in the modern sense (i.e., they describe something). On the distinction between ancient and modern ecphrasis and the Hellenistic development of ecphrasis see Goldhill 1994, Männlein-Robert 2007, and Webb 2009. 
While Pindar had, to some extent, relied on autopsy to inform his encomium (e.g., in Ol. 8.19-20, 10.100-105), Posidippus goes further by dispensing with any address to the reader that situates him or her in the act of viewing. In other words, the artifice of creating a spectacle of viewership is absent and the epigram reconfigures its readers as spectators at the games or in a sanctuary. In $\mathrm{AB} 76$, for example, the epigram opens by describing a horse

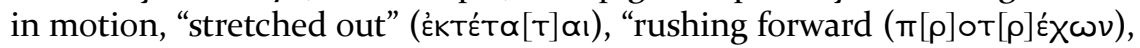

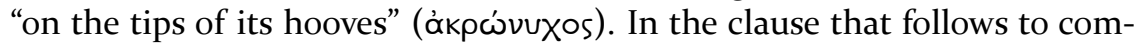

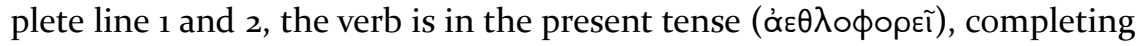
the idea that we are at the site itself and watching the horse rush to victory. The epigram does not specifically delineate a statue and is ambiguous in the scene it imagines; the reader is temporally and spatially transported to a victory at Delphi and its commemoration. While epinician song also conflates victory rituals as it represents them, Posidippus' description integrates the literary rendering of the dedication into the narrative of the race itself: the race ends, figuratively, with the transmutation of the horse into stone and song.

While the connection of Posidippus with epinician might seem obvious (he celebrates athletic victory, after all), the synthesis of "reading" and "viewing" and the ambiguous "performance" context mark the epigrammatist as an explicitly epinician poet in the mode of Pindar and Bacchylides. The creation of audiences within a poem is a case in point. In an inscription attached to a monument, there is no question of signalling an audience, at least explicitly, since the audience for an inscription at Olympia is those visiting Olympia. In Posidippus' epigrams, however, the second-person forms and vocatives in combination with the named sanctuary create fictional audiences. When the speaking voice of $A B 80$ addresses Nemean Zeus, the poem constructs an audience of fellow visitors to the sanctuary of Nemea; when, in $A B$ 85, the speaking voice addresses Zeus of Pisa, the audience become visitors to the sanctuary of Olympia. In this way, Posidippus' epigrams, though they borrow heavily from the tradition of inscribed verse, accord with audience expectations of epinician song, because their particular context of performance is ambiguous: that is, the poems can be read in Alexandria and prompt an imaginary landscape of Olympia. ${ }^{18}$ Pindar and Bacchylides also create audiences in their texts, whether sanctuary visitors (e.g., Ol. 9.111-112; Nem. 2.24-25), processional singers for a homecoming celebration (e.g., Ol. 11.13-19), or fellow sympotic revelers (e.g., Ol. 1.9-11, 6.99-100, 7.1-6; Nem. 1.19-25). Indeed, epinician song seems to be designed to efface its performance context so that subsequent performances still retain their immediacy. ${ }^{19}$ Epinician song offers a suggestive analogue to the Hippika because, similarly, the first performance context for the Hippika is unclear, and likewise, the texts were

${ }^{18}$ Pindar also uses imagined landscapes to orient his audience and add to the praise of his victor, see Eckerman 2013.

${ }^{19}$ On epinician songs's furtive performance milieu, see Carey 2007: 199. 
clearly circulated soon after, unattached to their initial performance (and, if they were not originally inscriptions, the only "performance" they have is a fictional "reperformance"). ${ }^{20}$

$\mathrm{AB} 78$ offers a concrete example of the Hippika's ambiguous performance context and its creation of imagined audiences. ${ }^{21}$ The poem's open-

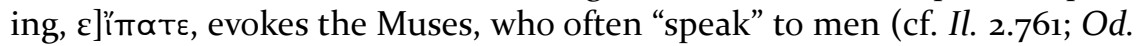

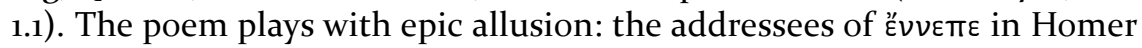
are the Muses, whereas here the poet addresses the performers/audience themselves. The connection with epic is made explicit following the vocative phrase, since the topic that "all the singers" (78.1-2) should sing is the kleos of the speaker. In a Ringkomposition structure, the end of the poem returns to address the audience again, though this time they are config-

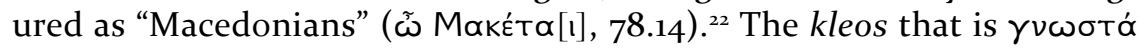
and that áoı $\delta \circ$ ire asked to sing is the abstract and generalized version of the specific [бтદ́pavov of the end of the poem (78.14); the Macedonians

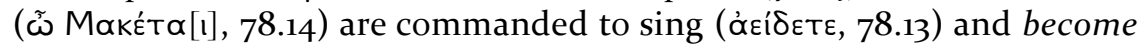

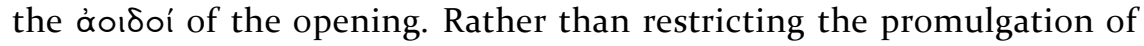
kleos to the class of professional singers, Posidippus' poem transforms its audience into singers, and Berenice's specific crown into a general form of kleos. ${ }^{23}$ Just as Pindar works to equate himself with Homer and his victor and victor's accomplishment with the martial success of Homeric heroes ${ }^{24}$ so too does Posidippus evoke Homer and connect this enunciation of victory with the continual reperformance tradition of epic. Despite the alterations of genre, medium, and metre, Posidippus' Hippika, like epinician song, connect athletic victory to martial (especially Homeric

${ }^{20}$ Epinician song also relies, at times, explicitly on visual language (e.g., Ol. 8), but also on conceiving of victory as brilliant and seen from far away (e.g., Pyth. 7). On epinician reperformance scenarios, see Currie 2004 and Hubbard 2004.

${ }^{21}$ I follow Thompson's reconstruction of the identities of the various Ptolemaic royals in this poem (Thompson 2005: 273-279): the speaker is Berenice "The Syrian" (daughter of Ptolemy II Philadelphus and sister of Euergetes); the grandfather (3) is Ptolemy I Soter; the "mother of my father" is Berenice I (5); the father is Ptolemy II Philadelphus (6-7).

${ }^{22}$ On Posidippus' defining the Ptolemies as Macedonians, see Thompson 2005. Posidippus himself also boasts of his specifically Macedonian lineage (AB 118.7).

${ }^{23}$ On the transformation of audience into poet in the reading aloud of inscribed epigram, see Day 2010. The ancient practice of reading aloud turns all readers into performers and poets, and illiterate companions into audience. In this way, inscription is always a performance script and reperformance is part of the generic inheritance of epigram with which Posidippus interacts. Posidippus' ambiguous relationship with monuments means that this could be a complete fiction that simply places us in the presence of a Familiengruppe-like statue, or it could be a copy of an inscription from a Familiengruppe (see Kosmetatou 2004). On patronage in this poem's opening and closing, see Ambühl 2007: 275 et passim.

${ }^{24}$ Miller 2018: 22-24. 
and epic) success and the work of the athletic-praise poet to that of the epic poet. ${ }^{25}$

Even though Posidippus' epigrams match the epinician songs of Pindar and Bacchylides for performance allusiveness and epic intertextuality, their approach to athletic encomium differs in at least one marked element: in contrast to epinician, Posidippus' epigrams narrate the athletic victory itself. While Classical epinician song includes mythic narratives that evoke athletic achievement through heroic analogies, the actual description of athletic achievement plays a minor role in encomium (appearing only at Ol. 8.67-69, 9.91-92; Pyth. 5.49-51, 8.81-87, 10.8-9, 11.49-50; Nem. 10.25; Isthm. 4.29-30, 5. 59-6o, 8.64-65; Bacchyl. 5.36-45). ${ }^{26}$ Posidippus' epigrams, however, narrate events of the race and aftermath and include details of the way in which victory was achieved. ${ }^{27}$ In particular, horses are unusually active in the Hippika, and their treatment in the series is the most innovative aspect of Posidippus' epinician poetics. ${ }^{28}$

In a few epigrams from the Hippika, the narration of a race plays only a very minor role: in $A B$ 79, Berenice is described as having "left behind her

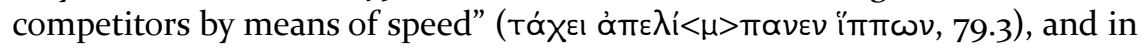
$\mathrm{AB} 86$, the epigram similarly begins by observing the horse's character: "boldly

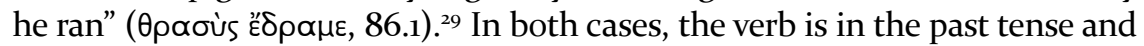
integrates a report of what had happened at the race..$^{30}$ Though relatively rare, this formation was not unknown in epinician song (perhaps most famously at Ol. 1.20-22). AB 73 is apposite: its beginning describes the opening of the race

${ }^{25}$ On other ways in which Posidippus interacts with Homer, most notably in the Lithika, see Petrain 2003; on thinking of Posidippus' poetic stance vis-à-vis Homer, see Nagy 2004.

${ }^{26}$ Even in earlier inscribed epigrams, the focus remains the postvictory rituals: see CEG 827 with Day 2007: 36-37. Rawles posits that Simonides may have had more athletic description, given the existence of chariot-race description in two fragments ( $P M G$ 516, 517; see Rawles 2012: 15). Bacchylides narrates slightly more of the athletic event; see Hadjimichael 2015. On epinician poetics and the problem of athletic narrative, see Miller 2018.

${ }_{27}^{27}$ Epigrams in general move toward narration; see Bowie 2010.

${ }^{28}$ Horses appear as instruments of equestrian victories in the Panhellenic games in inscribed epigram (e.g., $C E G$ 379, 778, 828); even in this usage, they can play formidable roles in a narrative of victory (e.g., $C E G$ 302, 820). CEG 888 refers

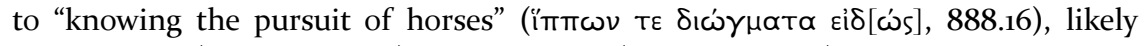
hippotrophia (cf. Pl. Plt. 310b) or a horse race (cf. Eur. Or. 988). In 828, the horses are

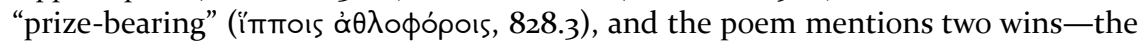
first, incredibly, while the victor was a Hellanodikes (see Paus. 6.1.4).

${ }^{29}$ Likely Berenice “The Syrian” (Thompson 2005: 273).

${ }^{30}$ This report builds on the proclamation of victory at the event itself. Since the

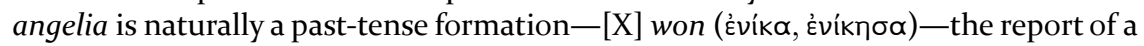
race is easily, though rarely, extrapolated from the announcement. 


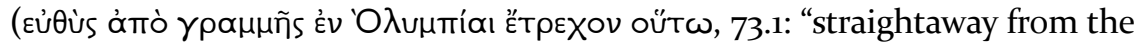
starting line in the Olympics he ran thus"), and the fragmentary second and third lines presumably extrapolate how the victory was won. ${ }^{3}$

$A B 72$ expands the race narrative considerably and demonstrates Posidippus' significant innovation in this area: neither epinician song nor inscribed epigram offers such a complete description. The poem begins by encouraging us to view the horse $(\theta \eta \varepsilon \tilde{\sigma} \sigma \theta \varepsilon, 72.1)$ and specifies the particular

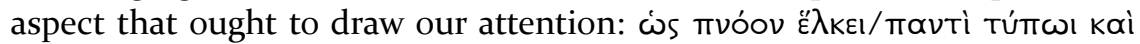

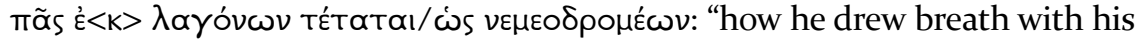
whole shape and everything was stretched out from the flanks as he ran the Nemean course," 72.1-3).32 The epigram describes the horse and directs our attention to its physical form as it runs a victorious race at Nemea. ${ }^{33}$ The use of the present tense here $(\theta \eta \varepsilon \tilde{\sigma} \sigma \varepsilon)$ indicates a repeated action (such as "take a look at"), and the continuous progressive aspect command is particularly apt for the focus on the horse's "indefatigable" quality. In line 3, the tense changes to the aorist (" $v \varepsilon \gamma \kappa \varepsilon, 72.3$ ), and the poem reports the result of the running at Nemea: the horse brought the celery (the Nemean victory crown) to Molycus. Line 4, however, adds an additional detail, namely that the horse "won by a

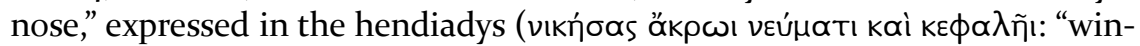
ning by the tip of its nod and a head," 72.4). Posidippus appears to be the first to use this phrase, which has had a long afterlife in racing and in horse-racing specifically (appearing in English as early as 1743; OED s.v. "head" I.1.b (b)).

The horse's nod in the poem works in at least two ways: first, it continues the effacement of the jockey that characterizes equestrian victories. ${ }^{34}$

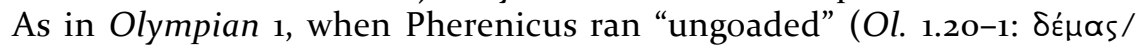
ákÉvтпTov), the horse here is the causal agent in "nodding," a move that would certainly require the jockey to pull at the bit and gear at the appropriate moment. ${ }^{35}$ Instead, the credit for this last-minute nod and therefore the victory is given over entirely to the horse, who is then imagined as bringing the crown directly to the victor. Second, "winning by a nod" perhaps makes the victory even more special. Pindar and Bacchylides use the motif of the

${ }^{31}$ The second line is fragmentary, but if any of the conjectures for this line are

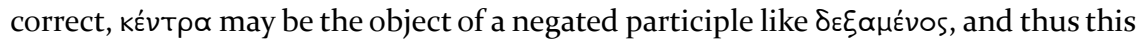
horse, like Pherenicus at $O l$. 1.21, needed no goad to spur it to victory (see conjectures in Angiò et al. 2016).

32 Ebert 1972: no. 12, a likely literary epigram, compares well here, even though it depicts the moment of coronation, rather than victory; on this epigram and its "Hellenistic" style, see Köhnken 2007: 299-300.

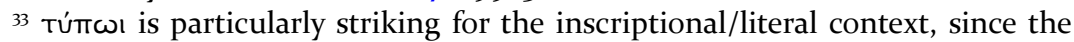
word is used for a figure sculpted in relief since at least Herodotus $(2.86,138)$.

34 On Classical epinician song's intentional obfuscation of the contributions of jockeys, charioteers, and trainers, see Nicholson 2005.

${ }^{35}$ My thanks to Carolyn Willekes for confirming this bit of equestrianism: the jockey may encourage the nod with a well-timed use of his whip. 
past "stolen victory" to emphasize the current victory, but Posidippus here creates a situation where his victor almost loses, but manages, at the last minute, to win; surely, the precariousness of victory increases its appeal. ${ }^{36}$ Not only does this race detail add to the glory of the victory, but also, perhaps more importantly, the description focuses attention on the body of the horse and therefore creates an enduring "monument" in the text itself. Posidippus' dynamic description of the race paradoxically contributes to a reification (if only literary and imaginative) of a statue of a perpetually striding horse dedicated in the sanctuary.

$\mathrm{AB} 74$, the longest and most complex epigram in the Hippika, also uses the "stolen victory" motif to describe a special victory, and it demonstrates Posidippus' indebtedness to epinician, and his innovative focus on the horse as the agent of victory. The first two and a half lines describe victory in the past tense with a brief mention of a competitor and the final "win with a nod"

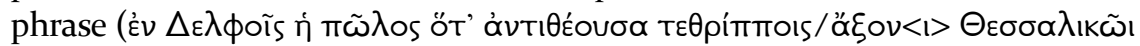

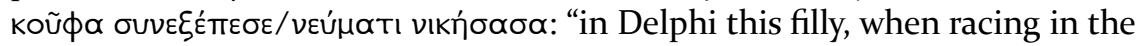
four-horse chariot race, was neck-and-neck with a Thessalian, won by a nod,"

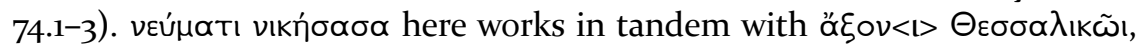
since the speed of the Thessalian rival explains why the victor won by such a small margin. ${ }^{37}$ Both aspects play out in the remainder of the epigram, which tells the fantastic story of a conflict over the true winner of the event, and the choice by the judges to have the drivers draw lots (74.3-6). One of the horses (the right trace-horse) selects a rod from the ground (left by the judges for the drivers to select), and her chariot is immediately signalled as the victor

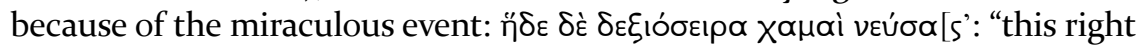
trace-horse having nodded to the ground" (74.7). Telling this story permits the horse to win "by a head," as it were, twice: first in the race itself (vEúpatı

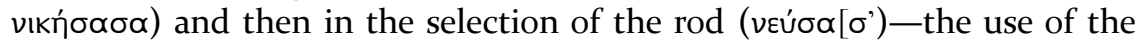
denominative verb recalls the importance of "nodding" and makes this horse the most active equestrian victor of all. Not only does she not need a jockey to win, but she is so special that she does not need a jockey in the aftermath

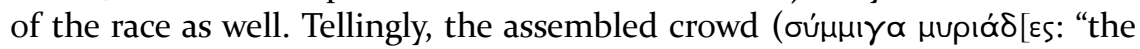
crowd altogether," 74.10) heralds her as the victor ( $\mu \varepsilon ́ \gamma \propto v$ : "to crown her with a great crown," 74.11). All the ancillary parts of athletic competition and its results are effaced (judges, umpires, heralds, jockeys, charioteers), and Posidippus focuses only on the horse.

${ }^{36}$ In this manner, Roman epitaphs for charioteers are not irrelevant: they mark "come from behind" victories, etc. See CIL 14.2884, for example, in which Diocles boasts of having "come from behind," "won in the last dash," etc. As far as I can tell, Posidippus' race descriptions are the first instance of finding extra quality in a particularly thrilling type of victory (though, of course, they relate to boasts to have led "wire-to-wire," such as that in Bacch. 5.44).

37 Thessalian horses were the most famous of Greek breeds (Anderson 1961: 23ff); see further below. 
The Equine ANGELIA

Across five epigrams ( $\mathrm{AB} 72,75,76,86,87)$, horses are the active agents in bearing crowns to their patrons, and their agency permits Posidippus, even more than his epinician predecessors, to focus exclusively on the horse..$^{8}$ Posidippus builds on the representation of Pherenicus, who

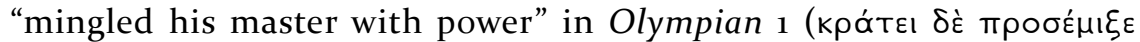
$\delta \varepsilon \sigma \pi o ́ t a v, O l .1 .21-22$ ), and the description of the same horse in Pythian 3, when Pherenicus is remembered for having "seized crowns" (Pyth. 3.74); perhaps most similarly, in Bacchylides 5, Pherenicus returned to Syracuse "bearing leaves of good fortune to Hieron," that is, crowns

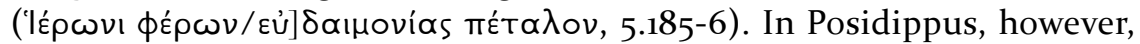
the metaphor of "seizing" or "bringing" is built into the structure of the narrative. $A B$ 72, again, provides a good example, since after the "win

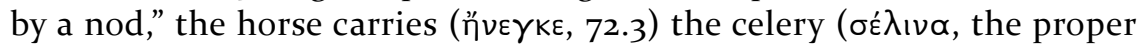
crown of the Nemean Games, 72.3) to the victor Molycus (72.3-4).39 While $A B 75$ and $A B 76$ are slightly more ambiguous, mainly because of lacunae in the text, crowns nonetheless seem to be the object of verbs

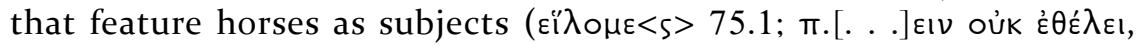
76.4). In $A B$ 86, the speaker of the poem (the victor, whom the epigram seems to imagine standing beside us as we view a statue of "this horse" [86.2]) narrates a victory catalogue and ends by turning to himself:

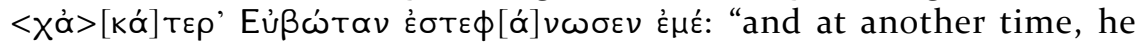
[the horse] crowned me, Eubotas" (86.4); Posidippus gives the herald's duties over to the horse. AB 87 similarly focuses on the apparently literal bearing of a crown by the horse to the victor. In this poem, the speak-

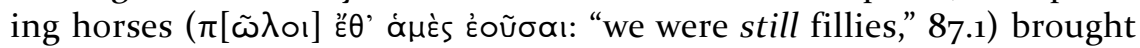

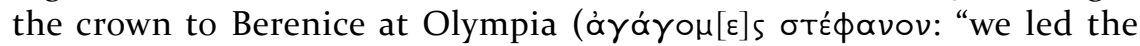
crown," 87.2). $4^{\circ}$

By assigning the traditional crowning duties to the horses themselves, Posidippus highlights their central role in these victories: not only are the horses the sole agents of victory, but also they actually bring the crowns to their victors. Considering the importance of the crown in the literal ritual of victory (and the subsequent dedication of crowns at the site) and its metaphorical use (as a stand-in for the victory itself), the placing of the horse as herald here is striking: while Pindar and Bacchylides effaced the jockey from the action of victory, Posidippus' equine herald even further erases

$3^{8}$ Golden also remarks on the increased agency of horses in the Hippika, their propensity to speak, and the fact that jockeys and charioteers are present but unnecessary (Golden 2008: 20-21).

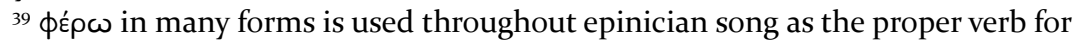
“to win” (e.g., Ol. 8.64, 9.98, 10.67; Pyth. 9.14; Isthm. 1.40, 7.21).

${ }^{40}$ Likely Berenice I, the wife of Ptolemy I Soter (Thompson 2005: 273). Fantuzzi makes clear the relationship of this poem and CEG 820 for Cynisca of Sparta (Fantuzzi 2005: 253-264). 
other possible foci during the literary representation of the competition and victory ceremony. ${ }^{41}$

Posidippus' focus on the horse as the agent of victory and its adjudication extends to the descriptions of horses in the Hippika. Whereas Pindar and Bacchylides gave some characterization to horses in equestrian victories (most notably, to Pherenicus in Ol. 1, Pyth. 3, Bacchyl. 5), and earlier agonistic epigrams occasionally mention horses by name, Posidippus goes much further in establishing an identity for his horses. ${ }^{42} \mathrm{He}$ mimics the epinician modulation of the angelia but forms an equine version that adds horse names as well as ages $\left(A B 7_{2}, 74,87\right)$, and ethnic origins $(A B 76,83,85,86)$. When we combine these categories with the event name and place of competition, we can recognize that Posidippus has carefully created a particularly equestrian angelia, which replaces or complements the representation of the proclamation of the victor. ${ }^{43} \mathrm{He}$ underscores the horse-as-herald motif through the horse's central place in its own proclamation.

The age of horses is a crucial aspect to Posidippus' equestrian angelia, and another element that comes from the actual herald's proclamation at the Games. In the Archaic and Classical period at Olympia, there were only three equestrian events, all of which involved adult horses (tethrippon, 68о вС; kelēs, 648 BC; synoris, 408 BC). ${ }^{44}$ By the time of Posidippus' victors, however, the

${ }^{41}$ The details of actual victory celebrations are frustratingly elusive, but Slater makes the case for crown dedication and Pindar's frequent metaphor of crown=song must have had a referent in reality (Slater 1984: 245). On crowns at different competitions and the evidence from a variety of sources, see Blech 1982.

${ }^{42}$ In the odes for Hieron of Syracuse, the horse Pherenicus ("Victory-bearer") plays a major role. In Bacchylides' Ode 5 , for example, he describes "chestnut-maned"

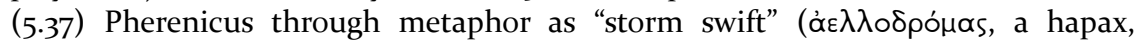
5.39). For more on this Olympic victory of Hieron, see Brousseau 2019: 392 in this collection. In two epigrams-not extant but reported by Pausanias-a horse played a major role in victory and was remembered for it: the story of Aura, who threw her rider yet still managed to run to victory, is likely apocryphal (Paus. 6.13.9). The sons of Aura's owner, Pheidolas, were, however, recorded to have won a victory for which they established a statue and epigram that celebrated their horse:

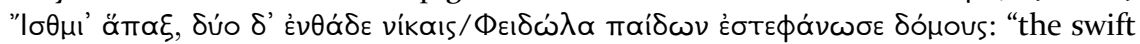
Lycus by one victory at the Isthmus and two here/crowned the house of the sons of Pheidolas." Here, too, the horse is imagined as the active agent in crowning the victors. Anth. Pal. 6.135 purports to be an epigram for Lycus; see Köhnken 2007:302-303.

43 The only category he lacks is father. The appearance, of course, of the horse's owner-the actual victor-in these epigrams may point to a substitution, whereby the horse is imagined as part of the victor's oikos and thus victor's name stands in the same relationship to horse as father's name to human victor; see below on hippotrophia and the oikos.

${ }^{44}$ The chariot race for mules existed at Olympia from 500 to 444 BC (Paus. 5.9.12; cf. Pind. Ol. 4, 5); the kalpe (for mares, but in the last lap the rider leapt off and ran with the horse with the reins) existed from 496-444 ВС (Paus. 5.9.1-2). 
four-horse chariot for foals ( $384 \mathrm{BC}$ ), the two-horse chariot for foals (264 BC), and the kelès for foals ( $256 \mathrm{BC}$ ) had been introduced. At Delphi, the tethrippon (582 BC) and kelès (586 BC) were ancient, but the other equestrian events were more recent innovations (synoris, 398 BC; tethrippon for foals, 378 BC; synoris for foals, 314 вС; kelēs for foals, 338 вс; see Paus. 10.7.5-8). Considering the novelty of the synoris for foals and the kelēs for foals at Olympia, it is perhaps unsurprising that age is a component of the horse's identity, since without indicating the horse's age, the event, often left unexpressed explicitly, would not be clear. Hence, for Posidippus' equestrian angelia, age does double duty: it expresses equine identity and a specific event. In $\mathrm{AB} 72$, when the persona loquens asks the audience to gaze at the horse, it specifies a colt ( $\pi \omega \dot{\lambda} \circ \mathrm{ov}, 72.1)$; in doing so, and with the noun in the singular, the event (the kelès for foals) is established and the participle $v \varepsilon \mu \varepsilon о \delta \rho \circ \mu \varepsilon \dot{\omega} \omega \nu$ (72.3) completes the representation of the angelia with the place of the contest. In $\mathrm{AB} 74$, along with the horse's sex, Posidippus completes the equestrian announcement by including the horse's age early in the poem-in fact, as the fourth word, $\pi \tilde{\omega} \lambda$ os (74.1). Here too, age completes the specification of the event.

$A B 87$ also indicates event (the four-horse tethrippon for foals at Olympia) but adds an element of narrative with the adverb "ै $\theta$ ' ("we were still fillies," 87.1). ${ }^{45}$ The epigram specifies the event but is also self-reflexive: the

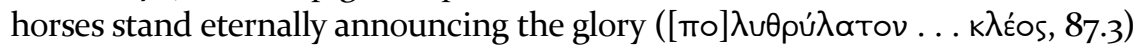
of Berenice. Athletic victory statues take into account, Leslie Kurke argues, the eventual disappearance of their victors, and, in this case, a possibly fictional epigram characterizes the speaking horses similarly: as figurative statues, they look back from a time when their mortal analogues have vanished. ${ }^{46}$ With their own death or old age imagined, the speaking equines look back from the present and recall their youth, when they won this long-lasting ( $\chi p o ́ v i o v, 87.4$ ) victory. ${ }^{47}$ In this epigram, age plays a role in the narrative of dedication and the publicizing of kleos, by emphasizing the time that has passed between victory, inscription, and report (the victory is, after all, much-spoken about) through the horses' own recognition of the passing years. ${ }^{4}$

45 This depends, of course, on the emendation in line 1: the ed. pr. min. suggests i $\pi[\pi \circ 1]$, though $\pi[\tilde{\omega} \lambda \circ 1]$ has been defended by Haslam (quoted in Stephens 2003) and De Stefani 2003. The line is further strengthened by the fact that there was no race for four mares at Olympia. Whether four mares could conceivably beat four stallions is unclear, but, certainly, for foals, any hormonal advantage would be diminished. Stephens (2003) suggests this is a reference to a "precocious victory, in keeping with the accomplishments of their precocious owner/queen." On the date of this victory and the probable event (chariot race for foals), see Stephens 2018.

${ }^{46}$ Kurke 1993: 147.

${ }^{47}$ On Pindar's claim to offer praise that has a "long life," see Ol. 4.10, Pyth. 3.115, Nem. 4.6.

${ }^{48}$ On тоте́ and other "inscriptional" motifs in epinician that also serve to imply the passage of time between composition and performance, see Young 1983. 


\section{Horse and Herald: Posidippus' Equestrian Angelia}

Whereas age reflects, among other things, a specific event, the ethnic origin of horses provides more specificity when it comes to equine identity. In breed, one might see an analogy to the polis element in the actual angelia, especially since horse breeds in Archaic and Classical Greece were geographical in significance rather than indicators of genetics or genealogy: any horse born and bred in Thessaly was Thessalian; any horse born and bred in Messenia was Messenian. ${ }^{49}$ Early evidence for horse-breeding beyond geographical adjectives is scant: Xenophon provides some general tips on selecting horses, which imply a knowledge of breeds, (Xen. Eq. 1.1-17), and Herodotus observes the different ethnic divisions of the Persian army and their "national" horses (7.86). Notably absent are "Arabian" horses: Arabs in the Persian army ride camels..$^{\circ}$

Specific horse ethnics are used in three of Posidippus' odes, $A B 76,83$, and 86; in $A B$ 85, there is an implied ethnic origin for the horse as well. In $\mathrm{AB} 76$, an epigram for Etearchus that celebrates his victory at the Pythian Games, the second line refers to the horse "who bore victory" as Arabian ("A]

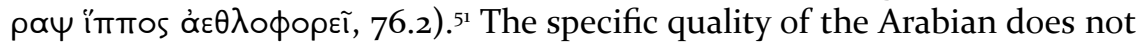
seem to add anything particular to the attaining of victory, though Dorothy Thompson collects evidence from papyri that may refer to "Arabian" horses, and she suggests that the Arabian horses characterize Etearchus as a connoisseur of all that the Ptolemaic empire has to offer. ${ }^{22}$ While "Arabian" may not have meaning in terms of a specific horse breed assisting in a victory, in the poem conceived as a supposed monument, it is potent: an "Arabian" horse is unusual and expensive, especially in its actual transport to Delphi. The ethnic specificity of the horse here adds lustre to the epigram qua monument and dedication at Delphi. We can therefore begin to see the encomiastic utility of Posidippus' focus on horses: horses can reflect the prestige (social, economic, or political) of the victor. ${ }^{53}$

49 See Anderson 1961: 38. The brands used on horses were symbols of regional identity; see Willekes 2016: 29-34.

${ }^{50}$ On the "Arabian" horse and its probable absence from antiquity, see Anderson 1961: 19. On ancient Greek horse breeds by region, see Anderson 1961: 21-33. In later writings, horse breeds take prominent roles in various Cynegetica: Gratius Faliscus 1.406ff; Nemesianus 204ff; Oppian 1.17off, 23off, 304ff. See Willekes 2019 in this collection.

${ }^{51}$ Arabian horses appear in no other literary source from Archaic through Hellenistic Greece. The other mention of "Arabian horsemen" in Posidippus is a conjecture (AB 10.9-10).

${ }^{2}$ Thompson 2005: 280 n. 66. As Arabian stones in the Lithika (AB 7.1, 16.1), the Arabian horse may also be an indicator of the exotic and thus of wealth (my thanks to one of the journal's anonymous readers for this observation).

53 Horse breeds appear in early Greek literature outside of Homer, such as Anacreon PMG 417 (a "Thracian") and Alcman PMGF 1 ("Enetic," "Colaxian," "Ibenian"); on the latter, see Devereux 1965, 1966. Horse types in Alcman PMG 1 are used such that the audience ought to know what they mean and how the respective breeds are ranked (cf. Eur. Hipp. 231, 1132). 
Two further horse breeds are mentioned in the Hippika: in AB 86, Aithon is a Messenian, a breed with good literary pedigree; the horses

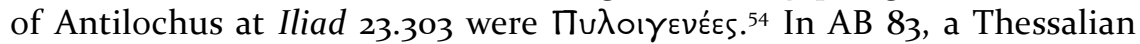
horse is impressive, and, finally, although the horse's ethnic origin is not mentioned explicitly, in $\mathrm{AB} 85$ the horse described as "distinguished for

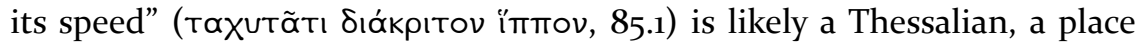
with great renown for horse breeding ("I did not end my Thessalian home-

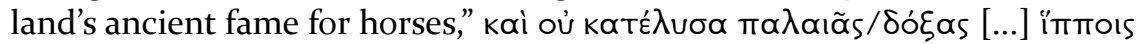

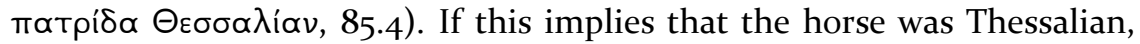
then presumably in $A B 83$ Thessalian is similarly meant to imply a particularly well-regarded horse breed (cf. Hdt. 7.196.1).55 Thessalian horses may in fact be the only horse breed about which something certain can be said in the Archaic through Hellenistic periods. Thessaly was renowned for its cavalry from an early period (e.g., Pl. Meno 7oa-b; Xen. Hell. 4.3.3-8, 7.5.15-17; Diod. Sic. 15.71.6), Thessalian hegemons minted coins with images of horses on them, and Thessalian cavalry were legendary for their performance at Gaugamela (Arr. Anab. 3.15.3). ${ }^{56}$ Once more, then, we may see in Posidippus' extreme focus on equine and equestrian details an added element in the praise of the victor: here, horse breed attaches the victor to a long tradition of martial success. ${ }^{57}$

\section{Hippotrophia ANd Praise of the Oikos}

AB 85 not only labels the horse Thessalian, but it situates the horse firmly

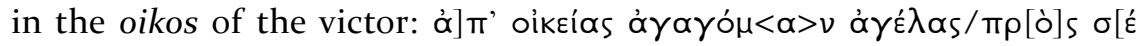
("I brought [it] from my own herds to you" [85.2-3]). The horse is described as coming from the victor's own herd-in other words, he presumably bred

${ }^{54}$ Hellenistic allusiveness and the interest in recherché references may be at work here: does "Aithon" bring to mind (to the erudite reader) "Aithe" (the name of the female horse of Menelaus at Iliad 23.409)? If so, the tables are turned, since "Aithon" in AB 86 is a male and Messenian while in the Iliad "Aithe" is female and of an unknown breed.

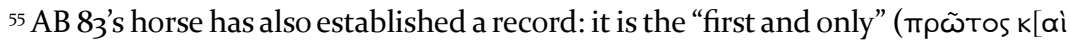
$\mu$ ]óvos, 83.3) horse to win three times at Olympia. The epigram challenges us to confirm the record ("check it," દ̇ $\lambda \dot{\gamma} \gamma \chi \varepsilon \tau \varepsilon, 83.3$ ) and claims the Iamidai, Olympic prophets, as witnesses to its superlative victory (83.4). On such "records," see Young 1996.

${ }^{56}$ For the coins, see Spence 1993: 23 n. 102. On Thessalian victors in the Hippika, see Scharff 2016. For other coins celebrating equestrian feats, see Brousseau 2019 in this collection.

${ }^{57}$ Classical epinician song also compares athletic with martial victors (e.g., through comparison with the Seven against Thebes, Ol. 6.12-21; with Herakles' stand against Apollo, Poseidon, and Hades, Ol. 9.28-35; with the Trojan War, Ol. 13.55-6o, Pyth. 3.112-14, Nem. 2.13-15, Nem. 6.49-53, Nem. 7.36-42, Isthm. 5.30-45).; Pindar's patrons are occasionally set up as contemporary martial heroes, such as Hieron after the defeat of the Carthaginians and Etruscans at Cumae, Pyth 1.47-80; Chromius at the Battle of Salamis, Nem. 9.31-40; or the unnamed uncle of one victor, Isthm. 7.23-25). Therefore, this may be another instance where Posidippus builds on epinician tradition. 
the horse himself. Horse breeding is attested early in the literary record: Simonides uses the specialized term hippotrophia (PMG 591) and Pindar praises Xenocrates of Acragas for his raising of horses (Isthm. 2.38); even in song for a pancration victory, hippotrophia burnishes the glory of family (Pind. Isthm. 4.28-29). Alcibiades' hippotrophia was a reason to boast of his wealth and political ability (Thuc. 6.12), and Aristotle regards hippotrophia as one of the distinguishing characteristics of the wealthy classes (Pol. 1289b35)..$^{8}$ Pausanias reports on an inscription at Olympia that boasts of hippotrophia: Cleogenes claims that "he won with a race-horse from his own

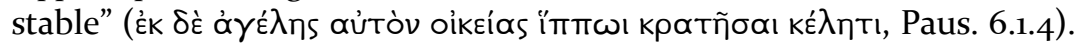

In $\mathrm{AB} 77$, regrettably fragmentary, hippotrophia is likely implied as well

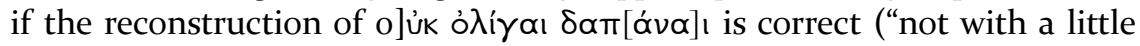
expense," 77.2). Across equestrian epinician, $\delta \alpha \pi \alpha ́ v \alpha$ is spent appropriately

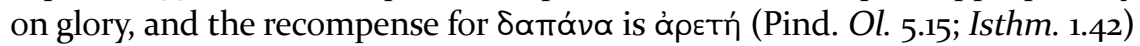
or "sweet song" (Pyth. 1.90). In fact, $A B 77$ may specifically refer to the raising

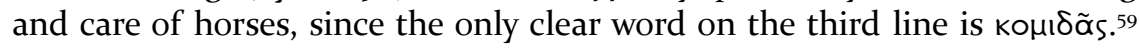
Returning to $\mathrm{AB} 85$, the specific reference to hippotrophia adds to Amyntas' glory, and, even more importantly, characterizes the horse as a gift particularly developed for its role as a personal dedication to Zeus ( $\pi \rho[\grave{o}] s \sigma[\varepsilon, Z \varepsilon] \tilde{u}$ Пıテव̃Ta: "to you, Zeus of Pisa," 85.3). The unnamed horse's victory is transformed from a single equestrian success into a component of a prayer and

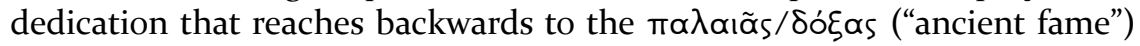
of Thessaly and forward in the eternal words of the figurative monument on which the epigram is inscribed: the horse is part of the oikos, the horse is a dedication, and the horse is a dedication from the victor. Posidippus' epigrams understand horses and equestrian victories as exactly what they are: the reason to race is to dedicate the victory to the gods, so Posidippus simply transforms the horse itself-in the moment of victory-into a dedication. ${ }^{60}$

The focus on creating an equine dedication builds on the motifs of equestrian praise in Classical epinician song. Even more than the patrons of Pindar and Bacchylides, Posidippus' patrons appear to have had no interest in memorializing the contribution of jockeys or charioteers; and Posidippus therefore includes almost no references to them. While Archaic and

$5^{8}$ On the importance of the horse to elite self-image, see Griffith 2006: 312-317.

59 If Austin's conjecture in Bastianini and Gallazzi 2001 is correct, a "sweet prize"

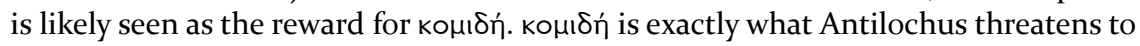
remove from his horses in the Iliad, should they fail to beat Menelaus (Il. 23.411); or the care to which Hector refers when asking his horses for a special task (Il. 8.186). In Iliad 8, Hector addresses his horses by name: Podargus, Aithon, and Lampus (8.185-

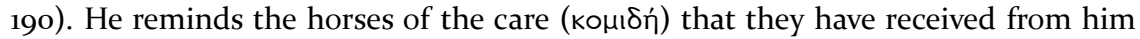
and Andromache; indeed, the latter even fed them sweet and mixed wine with their water-treating them just like her husband (Il. 8.190).

6o The horse's beauty can make it a dedicatory agalma and a sacrificial object: see Griffith 2006: 308-319. 
Classical representation of jockeys and charioteers is fraught, nonetheless, some appear-along with others such as trainers-and their participation in equestrian victory is not entirely absent. We cannot simply take the absence of the jockey, in particular, as a given, since the Horse and Jockey from Artemision demonstrates the potential for sculpting a monument that includes a jockey. ${ }^{61}$ The erasure of jockeys and charioteers speaks to an ideological program at work; this ideology can be further elucidated through this interpretation of Posidippus' equestrian angelia. Pindar and Bacchylides also focus on the horse, though the scope of reference is different and the amount of detail more copious in Posidippus. In Posidippus, the relationship between horse and patron takes centre stage: the horse, like its owner, may be imagined as the object of the herald's proclamation; horse breeds connect to geographically specific places and evoke the polis of the victor; horses' bodies are imagined as inheriting the care and time that a patron-and his

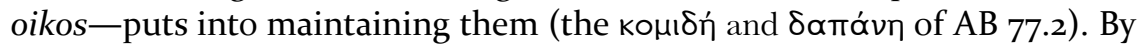
emphasizing the connection between owner and horse that emerges from the elite tradition of hippotrophia and by underscoring this connection through the representation of an equine angelia, Posidippus glorifies his patron's victory and family and removes any other possible focus for praise.

\section{CONCLUSION}

Posidippus' revitalization of the mode of athletic praise, if not its choral lyric form, creates complex, but brief, literary monuments. Like Classical epinician songs, Posidippus' poems assert no clear performance context, and therefore they can be read on papyrus rolls but imagined as inscriptions on monuments at the Panhellenic sanctuaries. Moreover, Posidippus' epinician epigrams maintain epinician song's focus on the glorification of the victor, and like Classical epinician, they do so only obliquely. Just as Pindar and Bacchylides praised their victors through mythical comparison, so Posidippus also finds substitutes to act as the explicit focus of his praise, in his case, the horses of the victors. Though Hellenistic kings, queens, and elites are his patrons, Posidippus' epigrams still work to praise through implication, and Hellenistic elites are imagined as Classical Panhellenic victors. ${ }^{62}$ Posidippus' epinician epigrams continue the epinician generic convention of building

${ }^{61}$ Dating on this statue is controversial and it has been placed anywhere from the fourth to the second century BC. See Hemingway 2004.

${ }^{62}$ Even in the Classical period, epinician and agonistic epigram treated the identities of rulers differently: the latter, at the Panhellenic site itself, removed any indication of elevated status from victors such as Gelon (see Harrell 2002: 439-451). Fantuzzi and Hunter also observe the Macedonian emphasis in Posidippus' poetry: the Ptolemies could not enter as "kings of Egypt" since non-Greeks were banned from the Olympics (Fantuzzi and Hunter 2004:394). The connection with Sparta (emphasized especially in AB 87) may be important, as Sparta was a model for kingship in the ancient Greek world (Fantuzzi and Hunter 2004: 397-398). 


\section{Horse and Herald: Posidippus' Equestrian Angelia}

on the angelia, but his epigrams move even further from the reality of the herald's speech act and convert the angelia and subsequent victory rituals into fodder, as it were, for equestrian praise.

Posidippus' poems dispense with the artifice of viewing; the poems describe athletic success through the supposed dedication that remembers that success. Horses are heralds of their patron's victories, but also the voices of imagined dedications; as they speed to the finish line, stretch out for victory, and dip their heads down, Posidippus' words transform them, as if through alchemy, from flesh and blood horses to statues whose existence is constructed through ink and whose presence, though delimited by the papyrus roll, extends the victor's kleos across time and space.

Department of Classics

UNIVERSITY OF WINNIPEG

pj.miller@uwinnipeg.ca

\section{REFERENCES}

Ambühl, A. 2007. "Tell, All Ye Singers, My Fame: Kings, Queens, and Nobility in Epigram," in P. Bing and J.S. Bruss (eds.), Brill's Companion to Hellenistic Epigram: Down to Philip. Leiden: Brill. 275-294.

Anderson, J.K. 1961. Ancient Greek Horsemanship. Berkeley: University of California Press.

Angiò, F., M. Cuypers, B. Acosta-Huges, and E. Kosmetatou. 2016. New Poems Attributed to Posidippus: A Text in Progress. Classics@ 1 (Version 13).

Austin, C. and G. Bastianini. 2002. Posidippi Pellaei Quae Supersunt Omnia. Milan: Edizioni Universitarie di Lettere Economia Diritto.

Bastianini, G. and C. Gallazi (eds.), with C. Austin. 20o1. Posidippo de Pella: Epigrammi (P. Mil. Vogl. VIII 309). Papiri dell'Università degli Studi di Milano, 8. Milan: LED.

Bettenworth, A. 2007. "The Mutual Influence of Inscribed and Literary Epigram," in P. Bing and J.S. Bruss (eds.), Brill's Companion to Hellenistic Epigram: Down to Philip. Leiden: Brill. 69-94.

Bing, P. 2009. The Scroll and the Marble: Studies in Reading and Reception in Hellenistic Poetry. Ann Arbor: University of Michigan Press.

Bing, P. and J.S. Bruss. 2007. "Introduction to the Study of Hellenistic Epigram," in P. Bing and J.S. Bruss (eds.), Brill's Companion to Hellenistic Epigram: Down to Philip. Leiden: Brill. 1-28.

Blech, M. 1982. Studien zum Kranz bei den Griechen. Berlin: De Gruyter.

Bowie, E. 2010. "Epigram as Narration," in M. Baumbach, A. Petrovic, and I. Petrovic (eds.), Archaic and Classical Greek Epigram. Cambridge: Cambridge University Press. 313-384.

Brousseau, L. 2019. "Athlètes, sports et jeux sur les monnaies antiques," Mouseion $16.3: 389-414$.

Bruss, J.S. 2010. "Epigram," in J.J. Clauss and M. Cuypers (eds.), A Companion to Hellenistic Literature. London: Wiley-Blackwell. 117-135.

Carey, C. 2007. "Pindar, Place and Performance," in S. Hornblower and C. Morgan (eds.), Pindar's Poetry, Patrons and Festivals. Oxford: Oxford University Press. 199-210. 
Currie, B. 2004. “Reperformance Scenarios for Pindar's Odes," in C.J. Mackie (ed.), Oral Performance and Its Context. Leiden: Brill. 48-70.

Day, J. 1994. "Interactive Offerings: Early Greek Dedicatory Epigrams and Ritual," HSPh 96: 37-74. https://doi.org/10.2307/311314

- 2007. "Poems on Stone: The Inscribed Antecedents of Hellenistic Epigram," in P. Bing and J.S. Bruss (eds.), Brill's Companion to Hellenistic Epigram: Down to Philip. Leiden: Brill. 29-48.

- 2010. Archaic Greek Epigram and Dedication. Cambridge: Cambridge University Press.

De Stefani, C. 2003. “Il 'nuovo Posidippo' di G. Bastianini, C. Gallazzi e C. Austin,” Orpheus 24: 55-87.

Devereux, G. 1965. “The Kolaxaian Horse of Alkman's Partheneion,” CQ 15(2): 176-184. https://doi.org/10.1017/sooo9838800oo8831

-1966. “The Enetian Horse of Alkman's Partheneion,” Hermes 94(2): 129-134. https://www.jstor.org/stable/4475397.</jrn>

Ebert, J. 1972. Griechische Epigramme auf Sieger an gymnasichen und hippischen Agonen. Berlin: Akademie Verlag.

Eckerman, C. 2013. "The Landscape and Heritage of Pindar's Olympia," CW 107(1): 3-33. https://doi.org/10.1353/clw.2013.0102

Fantuzzi, M. 2004. "The Structure of the Hippika in P. Mil. Vogl. VIII 309," in B. Acosta-Hughes, E. Kosmetatou, and M. Baumbach (eds.), Labored in Papyrus Leaves: Perspectives on an Epigram Collection Attributed to Posidippus (P. Mil. Vogl. VIII 309). Washington, DC: Center for Hellenic Studies and Harvard University Press. 212-224.

- 2005. "Posidippus at Court: The Contribution of the Immıx́ of P. Mil. Vogl. VIII 309 to the Ideology of Ptolemaic Kingship," in K. Gutzwiller (ed.), The New Posidippus: A Hellenistic Poetry Book. Oxford: Oxford University Press. 249-268.

Fantuzzi, M. and R. Hunter. 2004. Tradition and Innovation in Hellenistic Poetry. Cambridge: Cambridge University Press.

Golden, M. 20o8. Greek Sport and Social Status. Austin: University of Texas Press.

Goldhill, S. 1994. "The Naïve and Knowing Eye: Ecphrasis and the Culture of Viewing in the Hellenistic World," in S. Goldhill and R. Osborne (eds.), Art and Text in Ancient Greek Culture. Cambridge: Cambridge University Press. 197-223.

Griffith, M. 2006. "Horsepower and Donkeywork: Equids in the Ancient Greek Imagination," CP 101(3): 185-246. https://doi.org/10.1086/511015

Hadjimichael, T. 2015. "Sports-Writing: Bacchylides' Athletic Descriptions," Mnemosyne 68: 363-392. https://doi.org/10.1163/1568525X-12341389.

Harrell, S. 2002. "King or Private Citizen: Fifth-Century Sicilian Tyrants at Olympia and Delphi," Mnemosyne 55(4): 439-464. https://doi. org/10.1163/156852502760186233

Hemingway, S. 2004. The Horse and Jockey from Artemision. Berkeley: University of California Press.

Hubbard, T.K. 2004. "The Dissemination of Epinician Lyric: Pan-Hellenism, Reperformance, Written Texts," in C.J. Mackie (ed.), Oral Performance and Its Contexts. Leiden: Brill. 71-93.

Köhnken, A. 2007. "Epinician Epigram," in P. Bing and J.S. Bruss (eds.), Brill's Companion to Hellenistic Epigram. Leiden: Brill. 295-312.

Kosmetatou, E. 2004. "Constructing Legitimacy: The Ptolemaic Familiengruppe as a Means of Self-Definition in Posidippus' Hippika," in B. Acosta-Hughes, E. Kosmetatou, and M. Baumbach (eds.), Labored in Papyrus Leaves: Perspectives on 


\section{Horse and Herald: Posidippus' Equestrian Angelia}

an Epigram Collection Attributed to Posidippus (P. Mil. Vogl. VIII 309). Washington,

DC: Center for Hellenic Studies and Harvard University Press. 225-246.

Krevans, N. 2007. “The Arrangement of Epigrams in Collections," in P. Bing and J.S. Bruss (eds.), Brill's Companion to Hellenistic Epigram: Down to Philip. Leiden: Brill. 131-146.

Kurke, L. 1991. “The Economy of kudos," in C. Dougherty and L. Kurke (eds.), Cultural Poetics in Archaic Greece: Cult, Performance, Politics. Cambridge: Cambridge University Press. 131-163.

Lloyd-Jones, H. 2003. "All by Posidippus?” in D. Accorinti and P. Chuvin, Des géants à Dionysos: Mélanges de mythologie et de poésie grecques offerts à Francis Vian. Alessandria: Edizioni dell'Orso. 277-28o.

Mann, C., S. Remijsen, and S. Scharff (eds.). 2016. Athletics in the Hellenistic World. Berlin: Franz Steiner Verlag.

Männlein-Robert, I. 2007. "Epigrams on Art: Voice and Voicelessness in Ecphrastic Epigram," in P. Bing and J.S. Bruss (eds.), Brill's Companion to Hellenistic Epigram: Down to Philip. Leiden: Brill. 251-271.

Miller, P.J. 2018. "In the Shadow of Praise: Epinician Losers and Epinician Poetics," BICS 61(1): 21-41. https://doi.org/10.1111/2041-5370.12068

Nagy, G. 2004. "Homeric Echoes in Posidippus." in B. Acosta-Hughes, E. Kosmetatou, and M. Baumbach (eds.), Labored in Papyrus Leaves: Perspectives on an Epigram Collection Attributed to Posidippus (P. Mil. Vogl. VIII 309). Washington, DC: Center for Hellenic Studies and Harvard University Press. 57-64.

Nash, L.L. 1990. The Aggelia in Pindar. New York: Garland Publishing.

Nicholson, N. 2005. Aristocracy and Athletics in Archaic and Classical Greece. Cambridge: Cambridge University Press.

Nobili, C. 2016. Corone di gloria: Epigrammi agonistici ed epinici dal VII al IV secolo a.C. Hellenica, 58. Alessandria: Edizioni dell'Orso.

Nünlist, R. 1998. Poetologische Bildersprache in der frühgriechischen Dichtung. Stuttgart: B.G. Teubner.

Petrain, D. 2003."Homer, Theocritus and the Milan Papyrus (P. Mil. Vogl. VIII 309, Col. III 28-41)," CJ 98(4): 359-388. https://www.jstor.org/stable/3298248.

Rawles, R. 2012. "Early Epinician: Ibycus and Simonides," in P. Agócs, C. Carey, and R. Rawles (eds.), Reading the Victory Ode. Cambridge: Cambridge University Press. 3-27.

Remijsen, S. 2010. "Challenged by Egyptians: Greek Sports in the Third Century BC," in Z. Papakonstantinou (ed.), Sport in the Cultures of the Ancient World. London: Routledge. 98-123.

Scharff, S. 2016. "Das Pferd Aithon, die Skopaden und die maтpis $\Theta \varepsilon \sigma \sigma \alpha \lambda i ́ \alpha$. Zur Selbstdarstellung hippischer Sieger aus Thessalien im Hellenism," in C. Mann, S. Remijsen, and S. Scharff (eds.), Athletics in the Hellenistic World. Stuttgart: Franz Steiner Verlag. 209-230.

Sider, D. 2007. "Sylloge Simonidea," in P. Bing and J.S. Bruss (eds.), Brill's Companion to Hellenistic Epigram: Down to Philip. Leiden: Brill. 113-130.

Slater, W.J. 1984. "Nemean One: The Victor's Return in Poetry and Politics," in D.E. Gerber (ed.), Greek Poetry and Philosophy: Studies in Honour of Leonard Woodbury. Chico, CA: Scholars Press. 241-264.

Spence, I.G. 1993. The Cavalry of Classical Greece: A Social and Military History with Particular Reference to Athens. Oxford: Clarendon.

Steiner, D. 1998. "Moving Images: Fifth-Century Victory Monuments and the Athlete's Allure," ClAnt 17(1): 123-150. https://doi.org/10.2307/25011076. 
Stephens, S. 2003. "Review: Posidippi Pellaei Quae Supersunt Omnia," BMCRev 2003.09.19. Available at http://bmcr.brynmawr.edu/2003/2003-09-19.html.

- 2018. "P. Oxy. 17.2082 and Berenice I's Victory with Foals (Posidippus 87 A-B)," ZPE 206: 35-39.

Thomas, R. 2007. "Fame, Memorial and Choral Poetry: The Origins of Epinikian Poetry," in S. Hornblower and C. Morgan (eds.), Pindar's Poetry, Patrons and Festivals. Oxford: Oxford University Press. 141-166.

Thompson, D.J. 2005. "Posidippus, Poet of the Ptolemies," in K. Gutzwiller (ed.), The New Posidippus: A Hellenistic Poetry Book. Oxford: Oxford University Press. 269-286.

Webb, R. 2009. Ekphrasis, Imagination and Persuasion in Ancient Rhetorical Theory and Practice. Surrey, UK: Ashgate.

Willekes, C. 2016. The Horse in the Ancient World: From Bucephalus to the Hippodrome. London: I.B. Tauris.

Wolicki, A. 2002. "The Heralds and the Games in Archaic and Classical Greece," Nikephoros 15: 69-97.

Willekes, C. 2019. "Breeding Success: The Creation of the Racehorse in Antiquity," Mouseion 16.3: 453-70.

Young, D.C. 1983. "Pindar Pythians 2 and 3: Inscriptional moté and the 'Poetic Epistle," HSPh 87: 31-48. https://doi.org/10.2307/311249.

Young, D.C. 1996. "First with the Most: Greek Athletic Records and Specialization," Nikephoros 9: 175-197. 